\title{
Hypoxia-Ischemia Induces an Endogenous Reparative Response by Local Neural Progenitors in the Postnatal Mouse Telencephalon
}

\author{
Maria Dizon $^{a} \quad$ Francis Szele $^{c}$ John A. Kessler ${ }^{b}$ \\ Departments of a Pediatrics and ${ }^{b}$ Neurology, Northwestern University, Feinberg School of Medicine, Chicago, III., USA; \\ 'Department of Physiology, Anatomy and Genetics, University of Oxford, Oxford, UK
}

\section{Key Words}

Subventricular zone $\cdot$ White matter $\cdot$ Brain oligodendrocyte progenitor $\cdot$ Neurosphere $\cdot$ Regeneration

\begin{abstract}
Perinatal hypoxia-ischemia in the preterm neonate commonly results in white matter injury for which there is no specific therapy. The subventricular zone (SVZ) of the brain harbors neural stem cells and more committed progenitors including oligodendroglial progenitor cells that might serve as replacement cells for treating white matter injury. Data from rodent models suggest limited replacement of mature oligodendroglia by endogenous cells. Rare newly born mature oligodendrocytes have been reported within the striatum, corpus callosum and infarcted cortex 1 month following hypoxia-ischemia. Whether these oligodendrocytes arise in situ or emigrate from the SVZ is unknown. We used a postnatal day 9 mouse model of hypoxia-ischemia, BrdU labeling of mitotic cells, immunofluorescence and timelapse multiphoton microscopy to determine whether hypoxia-ischemia increases production of oligodendroglial progenitors within the SVZ with emigration toward injured areas. Although cells of the oligodendroglial lineage increased
\end{abstract}

in the brain ipsilateral to hypoxic-ischemic injury, they did not originate from the SVZ but rather arose within the striatum and cortex. Furthermore, they resulted from proliferation within the striatum but not within the cortex. Thus, an endogenous regenerative oligodendroglial response to postnatal hypoxia-ischemia occurs locally, with minimal long-distance contribution by cells of the SVZ.

Copyright $\odot 2010$ S. Karger AG, Basel

\section{Introduction}

Perinatal hypoxia-ischemia (HI) brain injury is a significant health problem with repercussions not only for the neonatal period but also for the entire life span. Annually, 150,000 newborns are affected. HI results in both gray and white matter damage in the full term, whereas white matter injury (WMI) predominates in preterm newborns [Volpe, 2001]. Cerebral palsy, the clinical correlate of WMI, is a nonprogressive spastic disorder of motor control [Johnston and Hoon, 2006] that affects more than half of preterm babies weighing $<1,500 \mathrm{~g}$ at birth [Volpe, 2001]. Due to advances in neonatal intensive care, the affected preterm population continues to grow. Fur-

\section{KARGER}

๑) 2010 S. Karger AG, Basel

Fax +4161306 1234 E-Mail karger@karger.ch www.karger.com www.karger.com/dne
Maria Dizon, MD

Prentice Women's Hospital

250 E. Superior St. 5-2144

Chicago, IL 60611 (USA)

Tel. +1 312472 4323, Fax +1 312472 4329, E-Mail m-dizon@ northwestern.edu 
thermore, even late preterm neonates are at increased risk for cerebral palsy [Winter et al., 2002].

Currently there is no medical therapy to prevent or treat WMI, but the persistence of neural stem/progenitor cells (NSPC) within the postnatal brain, including the postnatal human brain, makes them attractive as potential replacement cells for regenerating damaged white matter. Starting at mid-gestation and continuing during postnatal development, oligodendrocyte progenitor cells (OPCs) arise from NSPC within the subventricular zone (SVZ) and migrate radially to populate the striatum, subcortical white matter and neocortex [Levison and Goldman, 1997; Suzuki and Goldman, 2003]. Some emigrated cells persist as progenitors, while others differentiate into mature oligodendrocytes (OLs) [Dawson et al., 2003]. Although this migratory phenomenon occurs to a greater degree during antenatal and postnatal periods, the process continues during adulthood [Menn et al., 2006]. Since perinatal HI occurs during a period of active OPC migration, this has been posited as an explanation for why WMI is characteristically seen following preterm birth [Volpe, 2001; Johnston and Hoon, 2006].

OPCs within the rodent SVZ are vulnerable to postnatal HI through both necrotic and apoptotic mechanisms [Brazel et al., 2004]. OPCs within the cerebral cortex are also vulnerable [Back et al., 2002]. Nonetheless, 4 weeks after injury, rare newborn OLs are found in the striatum, corpus callosum and infarcted cortex [Back et al., 2002; Zaidi et al., 2004; Ong et al., 2005]. It is not known whether these newly born cells arose from OPCs already present locally or from cells that immigrated from the SVZ. Emigration of OPCs from the SVZ increases following demyelinating injury in the adult mouse [Menn et al., 2006]. Furthermore, neurospheres (NS) generated from the SVZ of neonatal rats subjected to HI yield OLs more often than NS derived from nonlesioned rats [Felling et al., 2006]. Therefore, we sought to determine the source of new OLs seen near infarcted areas following postnatal HI.

\section{Materials and Methods}

\section{Animals}

Olig1-EGFP mice (GENSAT Project, Rockefeller University, New York, N.Y., USA) were maintained on a Swiss-Webster background and Nestin-EGFP mice (Anjenn Chenn, Northwestern University, Chicago, Ill., USA) were maintained on an FVB/N background and were used in accordance with institution guidelines. The day of birth was designated as postnatal day 0 (P0).
Neonatal Hypoxic-Ischemic Lesions

P9 mice were anesthetized with isoflurane, then the right common carotid artery was ligated and transected. After $2 \mathrm{~h}$ of recovery, the pups were placed in humidified hypoxia chambers ( $8 \%$ oxygen $/ 92 \%$ balanced air) kept at $37^{\circ} \mathrm{C}$ for $45 \mathrm{~min}$, were allowed to recover for $1 \mathrm{~h}$, then returned to the dam as previously described [Plane et al., 2004]. Mice were sacrificed 4-14 days post lesion (dpl).

\section{BrdU Administration}

BrdU (Sigma B5002, St. Louis, Mo., USA) $50 \mathrm{mg} / \mathrm{kg}$ was injected intraperitoneally (IP) 4 times/day at 5, 6 and $7 \mathrm{dpl}$. Mice were sacrificed $1 \mathrm{~h}$ after the last injection.

\section{Quantification of Infarcted Brain}

Mice were anesthetized with pentobarbital IP, brains removed and chilled in ice-cold PBS for $5 \mathrm{~min}$, cut into 1-mm sections using a stainless steel mouse brain slicer (Harvard Apparatus NP725032, Holliston, Mass., USA), incubated in 2\% triphenyl tetrazolium chloride (TTC) (Sigma T8877) in PBS for $20 \mathrm{~min}$ at $37^{\circ} \mathrm{C}$, then stored in $4 \%$ paraformaldehyde (PFA). Images were taken using a Nikon camera and Spot software (Nikon, Melville, N.Y., USA) and analyzed using Axiovision software (Carl Zeiss Vision, Thornwood, N.Y., USA). Cross-sectional areas of infarction were measured indirectly and infarct volumes calculated from these (infarct volume of the right hemisphere $=$ total cortex volume of the left hemisphere minus noninfarcted cortex volume of the right hemisphere) [Lin et al., 1993; Sola et al., 2005].

\section{Immunofluorescence}

Mice were anesthetized with pentobarbital IP, transcardially perfused with $0.9 \% \mathrm{NaCl}$ followed by $4 \%$ PFA in PBS, brains were removed, post-fixed for $2 \mathrm{~h}$ in ice-cold $4 \%$ PFA, cryoprotected in $30 \%$ sucrose in PBS, embedded and frozen in OCT Compound (Sakura Finetek 4583, Torrance, Calif., USA), cut into $10-\mu \mathrm{m}$ sections using a cryostat, and immunostained as described previously using antigen retrieval [Samanta et al., 2007]. Antibodies used were as follows: BrdU (Accurate OBT0030, Westbury, N.Y., USA), BrdU (Chemicon MAB3510, Billerica, Mass., USA), CNPase (Sternberger SMI91, Princeton, N.J., USA), GFAP (DAKO Z03340, Carpinteria, Calif., USA), GFP (Chemicon AB-16901), Olig1 (Chemicon MAB5540), Olig2 (Chemicon AB9610), MAP2 (BD Pharmingen 656320, San Diego, Calif., USA), NG2 (Chemicon AB5320), PDGFR $\alpha$ (Fitzgerald CD140a, Concord, Mass., USA), AlexaFluor 488 goat antirabbit IgG, AlexaFluor 594 goat anti-mouse IgG2a, AlexaFluor 594 goat anti-mouse IgG2b and AlexaFluor 647 goat anti-rat IgG (Invitrogen, Carlsbad, Calif., USA).

\section{Preparation of Slice Cultures and Time-Lapse Multiphoton}

Microscopy

Mice were anesthetized with inhaled isoflurane, then chilled on ice for $5 \mathrm{~min}$, brains were quickly removed, placed in a slurry of artificial cerebrospinal fluid (aCSF) (125 mM NaCl, $1 \mathrm{mM}$ $\mathrm{MgCl}_{2}, 2.5 \mathrm{mM} \mathrm{KCl}, 25 \mathrm{mM}$ glucose, $2 \mathrm{mM} \mathrm{CaCl}_{2}$ ) and cut into $300-\mu \mathrm{m}$ parasagittal sections using a vibratome. Slices were incubated in oxygenated aCSF at $22^{\circ} \mathrm{C}$ during collection, then transferred to continuously oxygenated aCSF at $35^{\circ} \mathrm{C}$ during imaging. Time-lapse imaging was performed using a custom-built multiphoton microscope as described previously [Nam et al., 2007]. 
Generation of Neurospheres

Mice were anesthetized $7 \mathrm{dpl}$ with pentobarbital IP, brains were removed, chilled in ice-cold neurosphere medium (NSM) [DMEM/F12, B-27 supplement 50× (Gibco 17504, Carlsbad, Calif., USA), N-2 supplement $100 \times$ (Gibco 17502), L-glutamine $100 \times$ (Invitrogen 25030), heparin sodium $10 \times$ (J.T. Baker M916-00, Phillipsburg, N.J., USA), penicillin/streptomycin 100× (Gibco 15070)] for $2 \mathrm{~min}$, then transferred to a mouse brain slicer and cut into $1.0-\mathrm{mm}$ coronal sections. The intact peri-infarct cortex was microdissected using tungsten needles, taking care to exclude the corpus callosum and SVZ. Collected tissue was minced using fine iris scissors, $200 \mu \mathrm{l}$ trypsin-EDTA $0.25 \%$ was added and tissue was incubated at $37^{\circ} \mathrm{C}$ in $5 \% \mathrm{CO}_{2}$ for $30 \mathrm{~min}$. Tissue was triturated into a single-cell suspension using a P200 Pipetteman, trypsin inhibitor was added, then cells were washed with NSM and centrifuged at $200 \mathrm{~g}$ for $5 \mathrm{~min}$ three times. Cells were resuspended in $1 \mathrm{ml} \mathrm{NSM}$ plus $20 \mathrm{ng} / \mathrm{ml} \mathrm{FGF-2} \mathrm{(R \& D} \mathrm{Systems} \mathrm{233-FB,} \mathrm{Min-}$ neapolis, Minn., USA). Viable cell concentration was determined by trypan blue exclusion and cell suspensions were diluted to a density concentration of $1 \times 10^{5}$ viable cells $/ \mathrm{ml}$. Cells were cultured in $25-\mathrm{cm}^{2}$ tissue culture flasks which had previously been coated with Polyheme (Sigma P-3932). NSM was changed every 3 days. NS were imaged, counted and measured on DIV7 using a Leica inverted microscope (Leica, Bannockburn, Ill., USA) and Axiovision 4.6 software (Carl Zeiss Vision) [Dizon et al., 2006]

\section{Statistics and Analysis}

Three to 9 mice were used per treatment group. Mid-striatal coronal sections were collected (between $+0.98 \mathrm{~mm}$ anterior to bregma and +0.38 posterior to bregma). For each animal, five $40 \times$ fields were captured from each of the following regions: SVZ, striatum, corpus callosum and cortex, using Axiovision 4.6 software (Carl Zeiss Vision). Image files were encoded, areas were measured and cells were counted in a blinded fashion using Axiovision 4.6 and Image J software (NIH, Bethesda, Md., USA). Cell counts per area were calculated for each field and these were averaged. The nonpaired Student's t test was used to test for significance with a $p$ value set at $<0.05$.

\section{Results}

\section{Postnatal HI Causes Reproducible Infarcts in the}

Olig1-EGFP Mouse

P9 Olig1-EGFP mice were subjected to postnatal HI, then TTC staining was performed on brain slices $48 \mathrm{~h}$ later. Infarction was demonstrated by lack of TTC staining and presence of white color [Lin et al., 1993; Sola et al., 2005]; by contrast, the contralateral side showed no evidence of infarction, staining dark red by TTC (fig. 1A). This method revealed reproducibly infarcted areas ipsilateral to the ligated carotid artery. Infarct volumes were calculated for all survivors (70\% survival) and averaged $32 \pm 7 \mathrm{~mm}^{2}$ (mean $\pm \mathrm{SEM}$ ); the percentage of infarcted brain was $19 \pm 4 \%$ (mean \pm SEM) (fig. 1B).

Postnatal Hypoxia-Ischemia Induces

Oligodendroglial Progenitors

\section{Postnatal HI Causes Regional Increases in PDGFR $\alpha+$ Cells}

We used immunofluorescence to probe for PDGFR $\alpha$ in order to characterize changes in OPCs [Rivers et al., 2008; Frost et al., 2009] in response to postnatal HI. At 7 $\mathrm{dpl}$, we found a significant increase in PDGFR $\alpha+$ cells within the SVZ [control: $412 \pm 23$ cells $/ \mathrm{mm}^{2}$ (mean \pm SEM), lesion: $587 \pm 43$ cells $/ \mathrm{mm}^{2}, \mathrm{p}=0.013$ ] (fig. 1D-D', E) and the striatum (control: $70 \pm 3$ cells $/ \mathrm{mm}^{2}$, lesion: $139 \pm 11$ cells $\left./ \mathrm{mm}^{2}, \mathrm{p}=0.003\right)\left(\right.$ fig. $\left.2 \mathrm{~A}-\mathrm{A}^{\prime \prime}\right)$. In contrast, there was no significant change in PDGFR $\alpha+$ cells within the corpus callosum (control: $623 \pm 37$ cells $/ \mathrm{mm}^{2}$, lesion: $576 \pm 29$ cells $/ \mathrm{mm}^{2}, \mathrm{p}=0.384$ ) (fig. $\left.2 \mathrm{~B}-\mathrm{B}^{\prime \prime}\right)$ nor in the cortex (control: $142 \pm 12$ cells $/ \mathrm{mm}^{2}$, lesion: $120 \pm 19$ cells $/ \mathrm{mm}^{2}, \mathrm{p}=0.29$ ) (fig. $2 \mathrm{C}-\mathrm{C}^{\prime \prime}$ ). Thus, postnatal HI led to increased numbers of PDGFR $\alpha+$ cells within the SVZ and striatum yet not within the adjacent corpus callosum nor more distant cortex.

The Olig1-EGFP Mouse Accurately Reports OPCs and Shows that Postnatal HI Does Not Alter Emigration from the SVZ

To determine whether increased OPCs in the striatum originated from the SVZ, we used a BAC transgenic reporter mouse in which EGFP is driven by the Olig1 promoter (Olig1-EGFP). We validated this reporter line by immunofluorescence, co-labeling cells with antibody to GFP and Olig1 (fig. 3A), GFP and Olig2 (fig. 3B), or GFP and PDGFR $\alpha$ (fig. 3C, $\mathrm{C}^{\prime}$ ). All GFP+ cells were Olig1+; however, not all Olig1+ cells were GFP+ (fig. 3A). Olig1 reporting efficiency was quantified within the corpus callosum as $39.2 \%$. In contrast, GFP marked $68.8 \%$ of Olig2+ cells, whereas GFP marked $83.0 \%$ of PDGFR $\alpha+$ cells. GFP+ cells were never co-labeled by GFAP (fig. 3D) nor MAP-2 (fig. 3E).

If SVZ cells contribute to OPCs within the injured striatum, they must migrate from the SVZ to the corpus callosum to the striatum and/or from the SVZ directly into the striatum. Using time-lapse multiphoton microscopy, we captured cell movement within cultured tissue slices harvested from lesioned and nonlesioned mice. Mice underwent HI injury on P9 and acute parasagittal slice cultures were made 4, 7 and $14 \mathrm{dpl}$. Fields including the SVZ, adjacent corpus callosum and striatum were imaged every $2 \mathrm{~min}$ for $4 \mathrm{~h}$. As a positive control for cell migration, we used the Nestin-EGFP reporter mouse; with this line we were able to show robust cell movement within the SVZ even after lesion (online supplementary video 1, www.karger.com/doi/10.1159/000313468). Using the Olig1-EGFP mouse, we found only rare longitudinal 


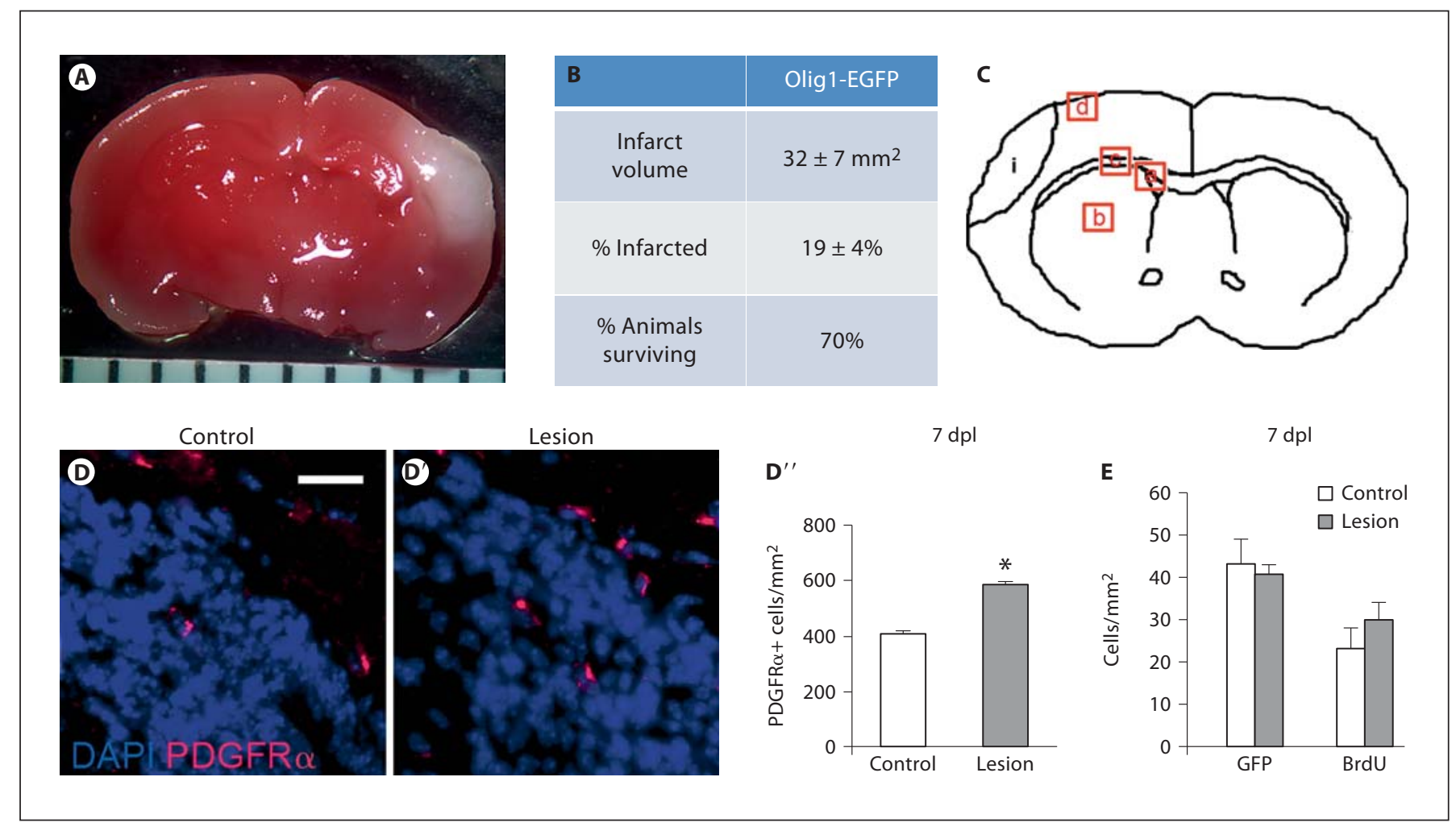

Fig. 1. The model creates reproducible injury in P9 Olig1-EGFP mice and induces an increase in PDGFR $\alpha+$ cells within the SVZ. A TTC staining was used to assess infarct size. A representative stained slice at the level of the hippocampus is shown $(1.3 \times$, ruler increments $=1 \mathrm{~mm}$ ). Infarcted tissue is white. B Infarct volume and percentage of brain infarcted $48 \mathrm{~h}$ after lesion were calculated and expressed as mean \pm SEM $(n=7)$. $70 \%$ of the animals survived to the time of TTC assay. C Four distinct telencephalic regions were examined: $\mathrm{a}=\mathrm{SVZ} ; \mathrm{b}=$ striatum; $\mathrm{c}=$ corpus callosum; $\mathrm{d}=$ peri-infarct cortex; $\mathrm{i}=$ the typical location of infarction. Five images of each region were captured from each animal $(n=3-9$ for each treatment group), images were encoded and cells counted with blinding to treatment group. D-D" Immunofluorescence for PDGFR $\alpha$ (red) on coronal sections obtained $7 \mathrm{dpl}$ showed a significant increase in PDGFR $\alpha+$ cells within the SVZ delineated by the DAPI+ cell-dense region (blue): control (magnification $\times 40$, scale bar $=50 \mu \mathrm{m})(\mathbf{D})$, lesion $\left(\mathbf{D}^{\prime}\right)$, quantification of PDGFR $\alpha+$ cells (error bars represent SEM, $\mathrm{n}=5$ controls and 7 lesions, ${ }^{*} \mathrm{p}=$ $0.013)\left(\mathbf{D}^{\prime \prime}\right)$. E No change in GFP+ cells was seen in the SVZ $7 \mathrm{dpl}$ (error bars represent SEM, $\mathrm{n}=5$ controls and 9 lesions). Immunohistochemistry for BrdU showed no significant change in BrdU+ cells within the SVZ $7 \mathrm{dpl}$ when animals were pulsed at 5, 6 and 7 $\mathrm{dpl}$ (error bars represent SEM, $\mathrm{n}=5$ controls and 9 lesions). movements of GFP+ cells along vectors oriented either from the SVZ towards the corpus callosum or from the corpus callosum towards the striatum in the unlesioned animal (online suppl. video 2); observations were not different in the lesioned animal (online suppl. video 3). After the injury, some cells exhibited exploratory-type movements, but this type of movement was also seen in nonlesioned slice cultures (data not shown). Thus, postnatal HI did not provoke Olig1-expressing SVZ cells to migrate to the striatum either directly or by way of the corpus callosum at subacute or chronic time points following injury.

\section{Postnatal HI Causes Regional Increases in Olig1 \\ Promoter Activation}

Despite the apparent lack of emigration of GFP+ cells from the SVZ in dynamic studies, we observed a significant increase in GFP+ cells within the striatum on static sections $7 \mathrm{dpl}$ [control: $666 \pm 46$ cells $/ \mathrm{mm}^{2}$ (mean \pm SEM), lesion: $860 \pm 127$ cells $/ \mathrm{mm}^{2}, \mathrm{p}=0.02$ ] (fig. $4 \mathrm{~A}-$ $\left.\mathrm{A}^{\prime \prime}\right)$. To test whether this increase merely reflected cell compaction following injury, we compared the density of DAPI+ cells and saw no difference between the nonlesioned and lesioned striatum (data not shown). If the corpus callosum were the immediate source of striatal GFP+ cells, then one might expect to see a decrease in GFP+ 

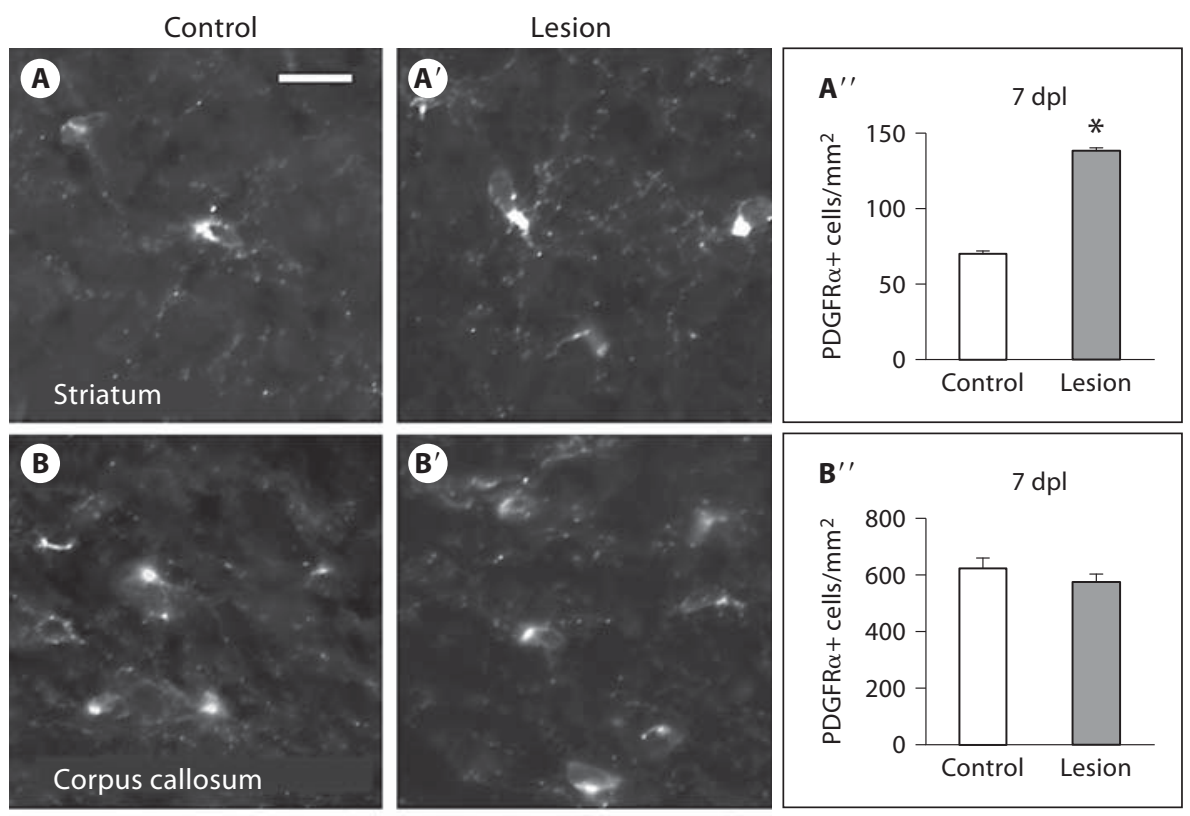

Fig. 2. HI increases PDGFR $\alpha+$ cells within the striatum. Immunofluorescence for PDGFR $\alpha+7 \mathrm{dpl}$ showed a significant increase in PDGFR $\alpha+$ cells within the striatum: control (magnification $\times 40$, scale bar $=50 \mu \mathrm{m})(\mathbf{A})$, lesion $\left(\mathbf{A}^{\prime}\right)$, quantification of PDGFR $\alpha+$ cells (error bars represent SEM, $\mathrm{n}=5$ controls and 7 lesions, $\left.{ }^{*} \mathrm{p}=0.003\right)\left(\mathbf{A}^{\prime \prime}\right)$; but no significant change within the corpus callosum: control (B), lesion $\left(\mathbf{B}^{\prime}\right)$, quantification $\left(\mathbf{B}^{\prime \prime}\right)$, and no significant change within the cortex: control (C), lesion $\left(\mathbf{C}^{\prime}\right)$, quantification $\left(\mathbf{C}^{\prime \prime}\right)$.
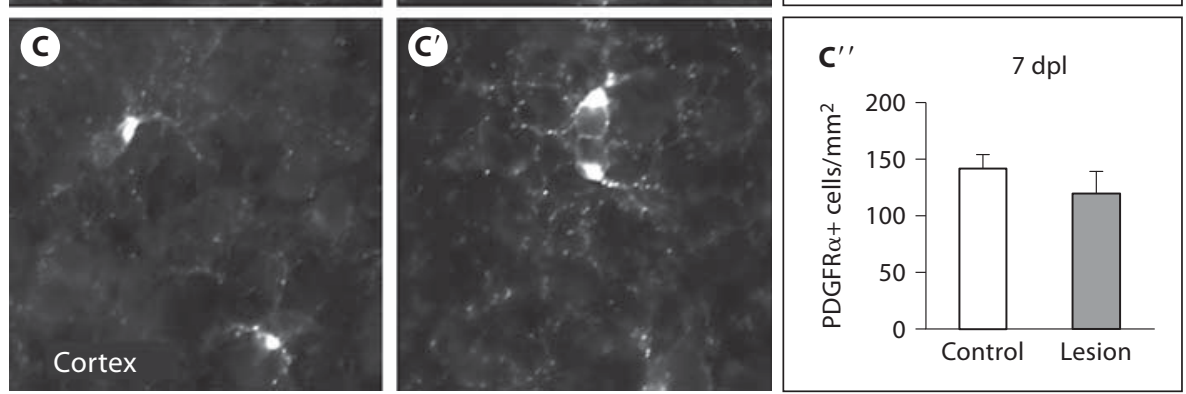

cells within the corpus callosum. In fact, we observed a significant decrease in GFP+ cells within the corpus callosum (control: $214 \pm 8$ cells $/ \mathrm{mm}^{2}$, lesion: $167 \pm 10$ cells/ $\mathrm{mm}^{2}, \mathrm{p}=0.0004$ ) (fig. 4B-B" $)$. However, cell death following $\mathrm{HI}$ is an alternate explanation for decreased GFP+ cells. If the SVZ was the immediate source of striatal GFP+ cells, then one might also expect to see a decrease in GFP+ cells within the SVZ. However, there was no significant change in the number of GFP+ cells (control: 43 \pm 6 cells $/ \mathrm{mm}^{2}$, lesion: $41 \pm 5$ cells $/ \mathrm{mm}^{2}, \mathrm{p}=0.791$ ) (fig. 1E). Since it was possible that emigration was matched by increased proliferation resulting in no change in GFP+ cells within the SVZ, we marked proliferating cells with BrdU at 5, 6 and $7 \mathrm{dpl}$. We found no change in BrdU+ cells within the SVZ (control: $23 \pm 2$ cells $/ \mathrm{mm}^{2}$, lesion: $30 \pm$ 4 cells $/ \mathrm{mm}^{2}, \mathrm{p}=0.122$ ) (fig. $1 \mathrm{~F}$ ). These findings are consistent with our dynamic imaging findings of minimal SVZ cell emigration. Interestingly, we also saw a significant increase in GFP+ cells at the intact peri-infarct cor- tex (control: $31 \pm 2$ cells $/ \mathrm{mm}^{2}$, lesion: $58 \pm 7$ cells $/ \mathrm{mm}^{2}$, $\mathrm{p}=0.007$ ) (fig. $4 \mathrm{C}-\mathrm{C}^{\prime \prime}$ ). Thus, our findings suggest that postnatal HI causes Olig1 promoter activation locally, not only within the striatum, but also within the intact periinfarct cortex $7 \mathrm{dpl}$.

\section{Postnatal HI Results in Region-Specific Loss of \\ Oligodendroglia}

To further explore events downstream of Olig1 promoter activation, we used immunofluorescence to probe for Olig1 protein $7 \mathrm{dpl}$. Despite increased GFP+ cells in the striatum and cortex, we did not see a corresponding increase in Olig1+ cells in these regions: control striatum: $533 \pm 42$ cells $/ \mathrm{mm}^{2}$ (mean \pm SEM), lesion striatum: 398 \pm 26 cells $/ \mathrm{mm}^{2}, \mathrm{p}=0.063$ (fig. $5 \mathrm{~A}-\mathrm{A}^{\prime \prime}$ ); control cortex: $60 \pm 12$ cells $/ \mathrm{mm}^{2}$, lesion cortex: $47 \pm 39$ cells $/ \mathrm{mm}^{2}$, $\mathrm{p}=0.782$ (fig. $5 \mathrm{~B}-\mathrm{B}^{\prime \prime}$ ). We attribute this discrepancy to the fact that the Olig1-EGFP mouse reports Olig2+ and PDGFR $\alpha+$ cells in addition to Olig1+ cells (fig. 2E). We 

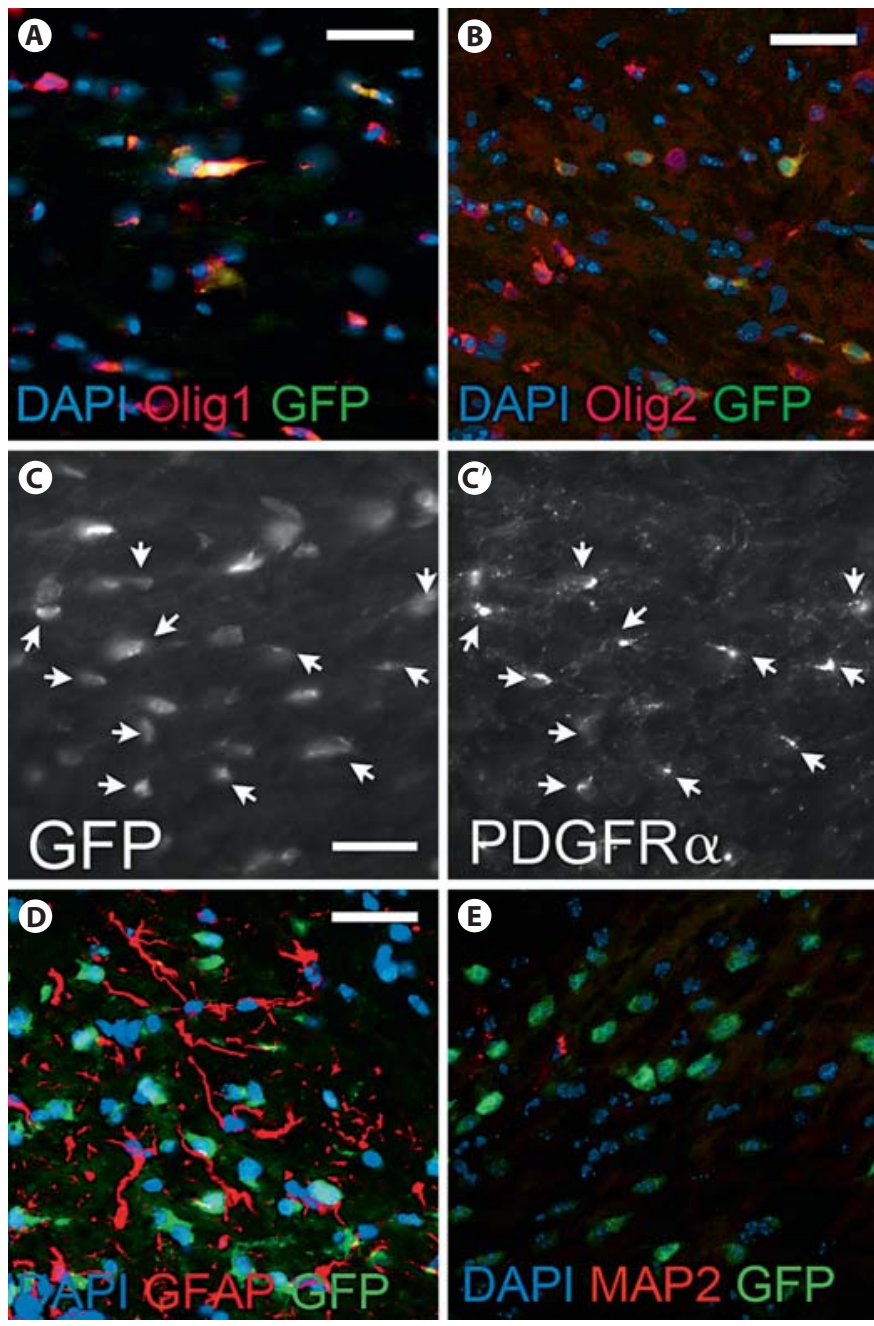

Fig. 3. The Olig1-EGFP mouse reports Olig1+, Olig2+ cells and PDGFR $\alpha+$ cells accurately. A Double immunofluorescence for Olig1+ cells and GFP+ cells at P14 shows all GFP+ cells co-labeling with Olig1 antibody within the corpus callosum [DAPI (blue), Olig1 (red), GFP (green), magnification $\times 40$, scale bar $=50 \mu \mathrm{m}$ ]. However, not all Olig1+ cells were co-labeled by anti-GFP antibody. B Double immunofluorescence for Olig2+ cells and GFP at P14 shows many GFP+ cells co-labeling with Olig2 antibody within the corpus callosum [DAPI (blue), Olig2 (red), GFP (green), magnification $\times 40$, scale bar $=50 \mu \mathrm{m}] . \mathbf{C}, \mathbf{C}^{\prime}$ Double immunofluorescence for PDGFR $\alpha+$ cells and GFP+ cells at P14 showed extensive overlap of cells within the corpus callosum [magnification $\times 40$, scale bar $=50 \mu \mathrm{m}$, arrows indicate co-labeled cells]. GFP+ cells never co-labeled with antibody to GFAP at P16 [DAPI (blue), GFAP (red), GFP (green), magnification $\times 40$, scale bar $=50 \mu \mathrm{m}, \mathrm{n}=3](\mathbf{D})$; nor with antibody to MAP2 at P14 [DAPI (blue), MAP2 (red), GFP (green), magnification $\times 40$, scale bar $=50 \mu \mathrm{m}, \mathrm{n}=3](\mathbf{E})$. did observe a decrease in Olig1+ cells in the corpus callosum (control: 2,075 \pm 267 cells $/ \mathrm{mm}^{2}$, lesion: 1,115 \pm 85 cells $\left./ \mathrm{mm}^{2}, \mathrm{p}=0.013\right)$ consistent with the findings of GFP (fig. 5C-C' $\mathrm{C}^{\prime \prime}$ ). At 4 weeks after the lesion, there was still no change in Olig1+ cells within the striatum (control: $307 \pm 18$ cells $/ \mathrm{mm}^{2}$, lesion: $373 \pm 15$ cells $/ \mathrm{mm}^{2}$, $\mathrm{p}=0.050$ ), but there was a trend towards increased Olig1+ cells, just meeting significance for the cortex (control: 119 \pm 7 cells $/ \mathrm{mm}^{2}$, lesion: $161 \pm 12$ cells $/ \mathrm{mm}^{2}, \mathrm{p}=0.049$ ) (data not shown).

\section{Proliferation Contributes to HI-Induced Increases in Striatal Olig2+ Cells}

Olig2 is expressed by OPCs, whereas Olig1 is also expressed at more differentiated stages including mature OLs [Ligon et al., 2006]. Thus, we used immunofluorescence to probe for Olig2 to further define the existence of a progenitor response $7 \mathrm{dpl}$. We found that Olig2+ cell counts increased in the striatum [control: $486 \pm 58$ cells $/ \mathrm{mm}^{2}$ (mean \pm SEM), lesion: $759 \pm 72$ cells $/ \mathrm{mm}^{2}$, $\mathrm{p}=0.044$ ] (fig. 6A) and in the cortex (control: $10 \pm 8$ cells $/ \mathrm{mm}^{2}$, lesion: $42 \pm 6$ cells $/ \mathrm{mm}^{2}, \mathrm{p}=0.037$ ) (fig. 6B). We found no differences in Olig2+ cell counts within the corpus callosum (control: $1,915 \pm 322$ cells $/ \mathrm{mm}^{2}$, lesion: $1,381 \pm 116$ cells $/ \mathrm{mm}^{2}, \mathrm{p}=0.234$ ) (fig. $6 \mathrm{C}$ ) nor the SVZ following lesion (control: 1,454 \pm 390 cells/ $\mathrm{mm}^{2}$, lesion: $986 \pm 99$ cells $/ \mathrm{mm}^{2}, \mathrm{p}=0.352$ ) (fig. $6 \mathrm{D}$ ), again suggesting that the SVZ is not the source of an $\mathrm{OPC}$ response to $\mathrm{HI}$.

To determine whether the observed increases in Olig2+ cells at the cortex and striatum following $\mathrm{HI}$ are due to proliferation, we injected the mice with BrdU at 5 , 6 and $7 \mathrm{dpl}$. We found increased Olig2+/BrdU+ cells within the striatum $7 \mathrm{dpl}$ (control: $0 \pm 0$ cells $/ \mathrm{mm}^{2}$, lesion: $40 \pm 7$ cells $/ \mathrm{mm}^{2}, \mathrm{p}=0.031$ ) (fig. $6 \mathrm{~A}$ ). We found no change in Olig2+/BrdU+ cells within the cortex (control: $0 \pm 0$ cells $/ \mathrm{mm}^{2}$, lesion: $5 \pm 2$ cells $/ \mathrm{mm}^{2}, \mathrm{p}=0.103$ ) (fig. 6B). The lack of significance may have been due to low numbers of cells sampled. Alternatively, with our timing of BrdU administration, we may have missed an earlier proliferative burst. Moreover, we did not find a change in Olig2+/BrdU+ cells within the corpus callosum (control: $181 \pm 7$ cells $/ \mathrm{mm}^{2}$, lesion: $189 \pm 30$ cells/ $\mathrm{mm}^{2}, \mathrm{p}=0.820$ ) (fig. 6C). An increase in BrdU has previously been reported within rat SVZ following postnatal HI [Ong et al., 2005]. Given that proliferation may have taken place within the SVZ prior to cells migrating to the striatum or corpus callosum, we also counted Olig2+/ BrdU+ cells in the SVZ. Although we observed a weak trend towards increased BrdU staining within the SVZ of 

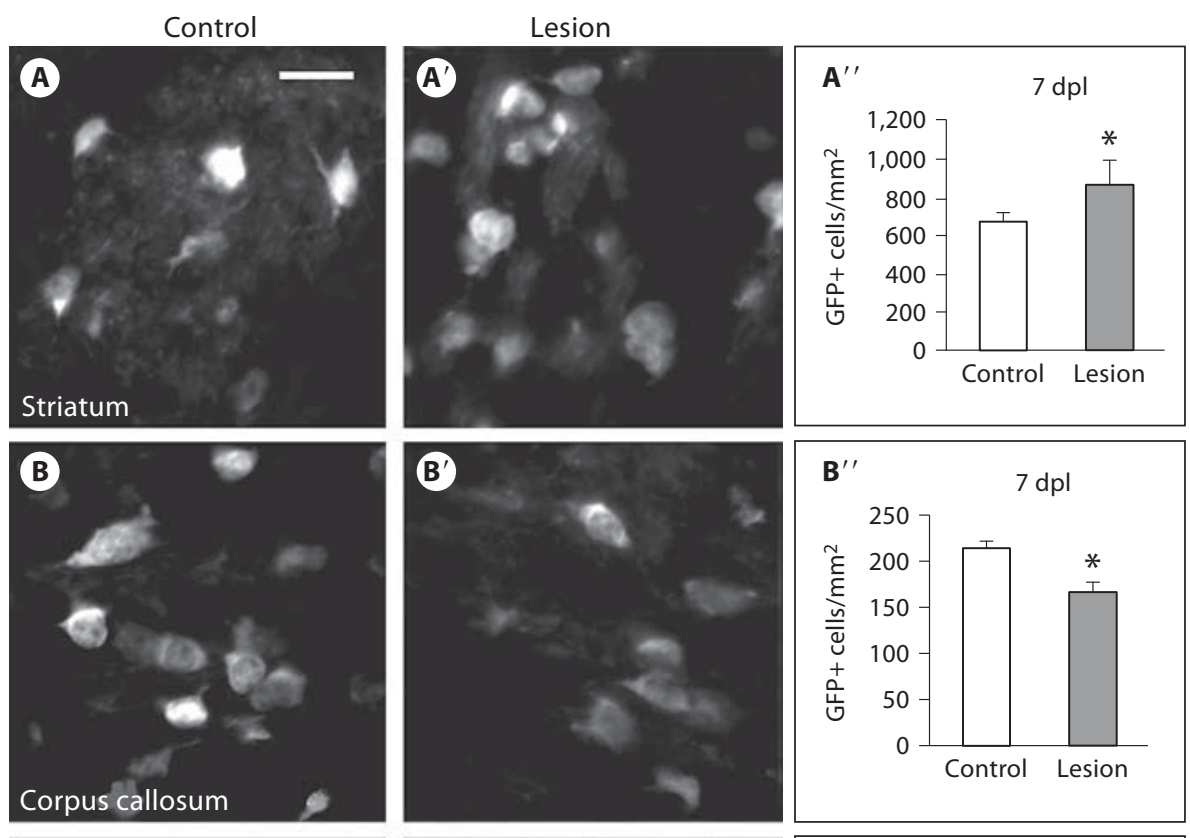

increases Olig1 promoter activation within the striatum and cortex. Coronal sections from the Olig1-EGFP reporter mouse showed an increase in GFP+ cells $7 \mathrm{dpl}$ within the striatum: control (A), lesion $\left(\mathbf{A}^{\prime}\right)$, quantification of GFP+ cells (error bars represent SEM, $\mathrm{n}=5$ controls and 9 lesions, $\left.{ }^{*} \mathrm{p}=0.028\right)\left(\mathbf{A}^{\prime \prime}\right)$; a decrease in GFP+ within the corpus callosum: control (B), lesion $\left(\mathbf{B}^{\prime}\right)$, quantification $\left({ }^{*} \mathrm{p}=\right.$ $0.0004)\left(\mathbf{B}^{\prime \prime}\right)$, and an increase in GFP+ cells within the intact peri-infarct cortex: control $(\mathbf{C})$, lesion $\left(\mathbf{C}^{\prime}\right)$, quantification $\left({ }^{*} \mathrm{p}=\right.$ 0.007) $\left(\mathbf{C}^{\prime \prime}\right)$.
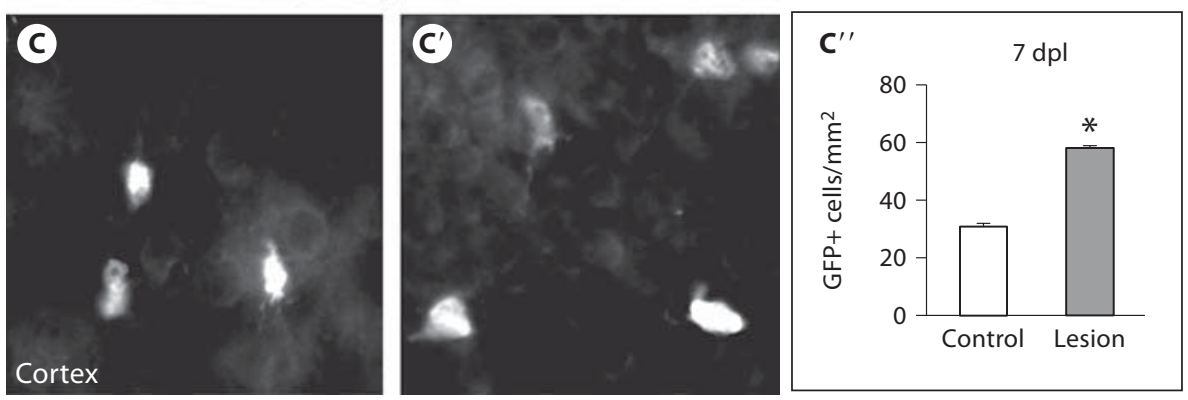

lesioned mice (fig. 1F), we found no change in Olig2+/ BrdU+ cells within the SVZ (control: $457 \pm 83$ cells/ $\mathrm{mm}^{2}$, lesion: $332 \pm 93$ cells $/ \mathrm{mm}^{2}, \mathrm{p}=0.373$ ) (fig. 6D). Thus, proliferation contributes to increases in Olig2+ cells following HI within the striatum.

To explore whether HI induced a change in the proliferation of cortical astroglial progenitors rather than oligodendroglial progenitors, we performed immunofluorescence for NG2, a marker of astroglial progenitors outside of the SVZ [Nishiyama et al., 2009]. NG2+ cell numbers did not increase within the cortex $7 \mathrm{dpl}$ [control: $325 \pm 10$ cells $/ \mathrm{mm}^{2}$ (mean \pm SEM), lesion: $357 \pm 16$ cells $/ \mathrm{mm}^{2}, \mathrm{p}=0.258$ ] (fig. $6 \mathrm{E}$ ), further suggesting that proliferation is not the mechanism for increased Olig2+ cells within the cortex.

To further explore the question of cortical progenitor proliferation, we generated NS from the cortex of lesioned and nonlesioned animals. The average diameter of NS derived from lesioned versus nonlesioned mice did not differ (control: $68.6 \pm 5 \mu \mathrm{m}$, lesion: $64 \pm 6 \mu \mathrm{m}, \mathrm{p}=$ 0.566 ) (fig. $6 \mathrm{~F}$ ). Thus, in vitro data also suggest no change in proliferation of cortical progenitors, whether astroglial or oligodendroglial.

\section{Discussion}

Although the etiology of neonatal brain injury is multifactorial, rodent studies suggest that HI plays a dominant role in the development of WMI. In P7 rats, Liu et al. [2002] showed a decrease in mature OLs evidenced by decreased MBP immunostaining $5 \mathrm{dpl}$ but MBP recovery 2 weeks after mild $\mathrm{HI}$ injury, suggesting either recovery of injured OLs or proliferation and/or differentiation of OPCs into new OLs. The latter mechanism is supported by Zaidi et al. [2004] who showed increased newly born mature OLs evidenced by BrdU+/MBP+ cells and BrdU+/ carbonic anhydrase+ cells 4 weeks after HI. Increases 
Fig. 5. HI causes loss of oligodendroglial cells within the corpus callosum. In contrast to GFP findings, immunofluorescence for Olig1 did not show an increase in Olig1+ cells $7 \mathrm{dpl}$ within the striatum: control (magnification $\times 40$, scale bar $=50$ $\mu \mathrm{m})(\mathbf{A})$, lesion $\left(\mathbf{A}^{\prime}\right)$, quantification of Olig1+ cells (error bars represent SEM, $\mathrm{n}=$ 3 controls and 4 lesions) ( $\left.\mathbf{A}^{\prime \prime}\right)$; nor within the cortex: control (B), lesion ( $\left.\mathbf{B}^{\prime}\right)$, quantification (error bars represent SEM) $\left(\mathbf{B}^{\prime \prime}\right)$. HI did cause a significant loss of Olig1+ cells within the corpus callosum: control (C), lesion $\left(\mathbf{C}^{\prime}\right)$; quantification of Olig1+ cells (error bars represent SEM, $\mathrm{n}=3$ controls and 4 lesions, $\left.{ }^{*} \mathrm{p}=0.013\right)\left(\mathbf{C}^{\prime \prime}\right)$.
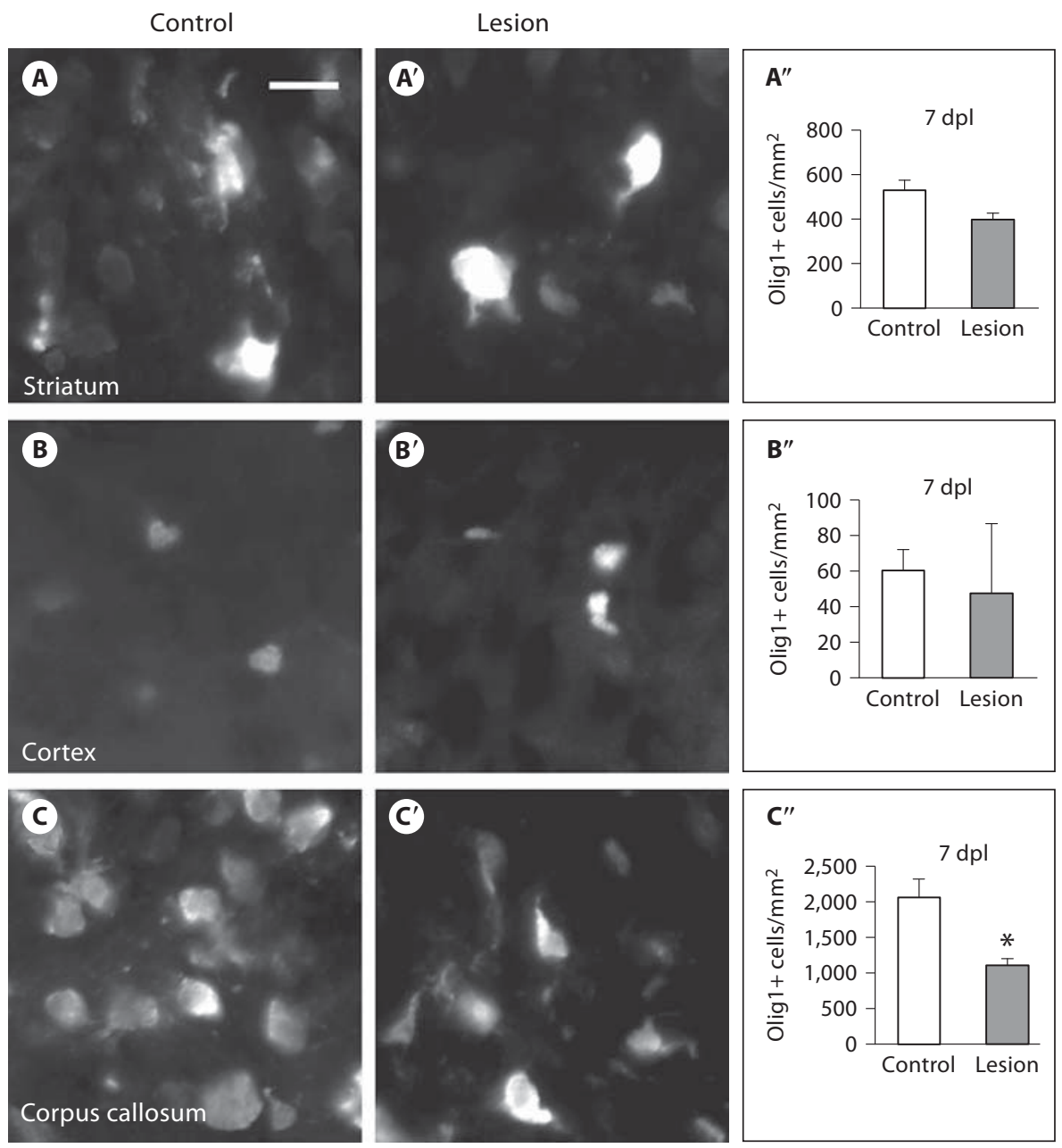

were seen in the striatum and infarct core, but were particularly abundant in the corpus callosum. They also reported increased BrdU+ cells 1 week following injury but did not double-label these cells with OL markers, so it is not clear whether newly born OLs derive from cycling OPCs or NSPCs [Zaidi et al., 2004]. Ong et al. [2005] added more evidence for newly born mature OLs, showing an increase in BrdU+/RIP+ cells 4 weeks after lesion in the striatum. In contrast, in a rat model of recurrent HI, Segovia et al. [2008] showed a robust accumulation of OPCs attributed to blocked differentiation and delayed apoptotic death. The source of these OPCs and newly born OLs is not known. Because OPCs normally migrate to subcortical white matter and cortex during the neonatal period, it was reasonable that the SVZ NSPCs might contribute OPCs as part of an endogenous reparative response.
We began by testing the hypothesis that OLs found near infarcted brain regions originate from SVZ OPCs. Although most studies of postnatal HI have utilized the rat, Craig et al. [2003] directly compared WMI in mouse versus rat and found them comparable. We chose to use a mouse model for our experiments in order to take advantage of transgenic technologies specifically to investigate alterations in cell migration. First, we demonstrated that HI caused an increase in cells capable of migration both at the presumptive source and at the destination. Following HI injury, we found increased numbers of cells in the SVZ that expressed PDGFR $\alpha$ which is found predominantly in migratory and mitotic OPCs [Rivers et al., 2008; Frost et al., 2009]. We also found increased PDGFR $\alpha+$ cells in the adjacent striatum. Since the bHLH transcription factor Olig1 is expressed by OPCs and is required in combination with Olig2 for the initial commitment of NSCs to the oligodendroglial lineage, 
and since it is expressed prior to and simultaneous with PDGFR $\alpha$, we used the Olig1-EGFP reporter mouse and multiphoton microscopy to determine migratory responses of OPCs to postnatal HI. We fully expected to see increased emigration of GFP+ cells out of the SVZ in response to HI but did not. In fact, we showed minimal migration of GFP+ cells despite the fact that the transcription factor Olig1 is required for the earliest commitment of NSPCs to OPCs. Our interpretation of these findings is that the SVZ contributes minimally if at all to increases in cells of the oligodendroglial lineage in the striatum following HI. An alternative explanation is that, since Olig1 is expressed throughout the oligodendroglial lineage, the signal of emigrating cells is obscured by the robust signal of nonmigratory cells. In either case, the number of such cells must be quite small. And, in fact, our studies showed that the Olig1-EGFP mouse also marks Olig2+ and PDGFR $\alpha+$ cells.

In light of these data, we then tested the altered hypothesis that new OLs found near infarcted brain regions in fact originate locally. Again using the Olig1-EGFP reporter mouse, we demonstrated Olig1 promoter activation in the striatum in response to postnatal HI. Consistent with Segovia et al. [2008], we also showed an increase in OPCs marked by Olig 2 localized to the striatum and cortex. The robustness of the response we observed differs from that reported by their lab, but this is likely due to their recurrent HI model [Segovia et al., 2008]. An alternative explanation for differences in magnitude of OPC response may be species differences. Our BrdU double-labeling studies indicated that proliferation contributes to increased Olig2+ cells in the striatum but not the cortex. The lack of a significant increase in the cortex may be due to the small number of cells sampled; however, the lack of proliferation within the cortex was further supported by cortical NS culture results. Despite increases in Olig2+ cells and PDGFR $\alpha+$ cells at $7 \mathrm{dpl}$, increases in Olig1+ cells were not found 4 weeks after lesion.

In conclusion, our findings demonstrate that an endogenous regenerative response by the oligodendroglial lineage exists locally within areas injured by postnatal HI, most robustly within the striatum. Our dynamic studies of Olig1+ cells show that, despite a response that includes the SVZ, the SVZ fails to contribute OPCs to remote or even adjacent regions. Our BrdU studies show that, within the striatum, postnatal $\mathrm{HI}$ induces resident Olig2+ cells to proliferate and in turn generate increased PDGFR $\alpha+$ cells. However, these cells fail to differentiate and persist as more mature Olig1-expressing cells.

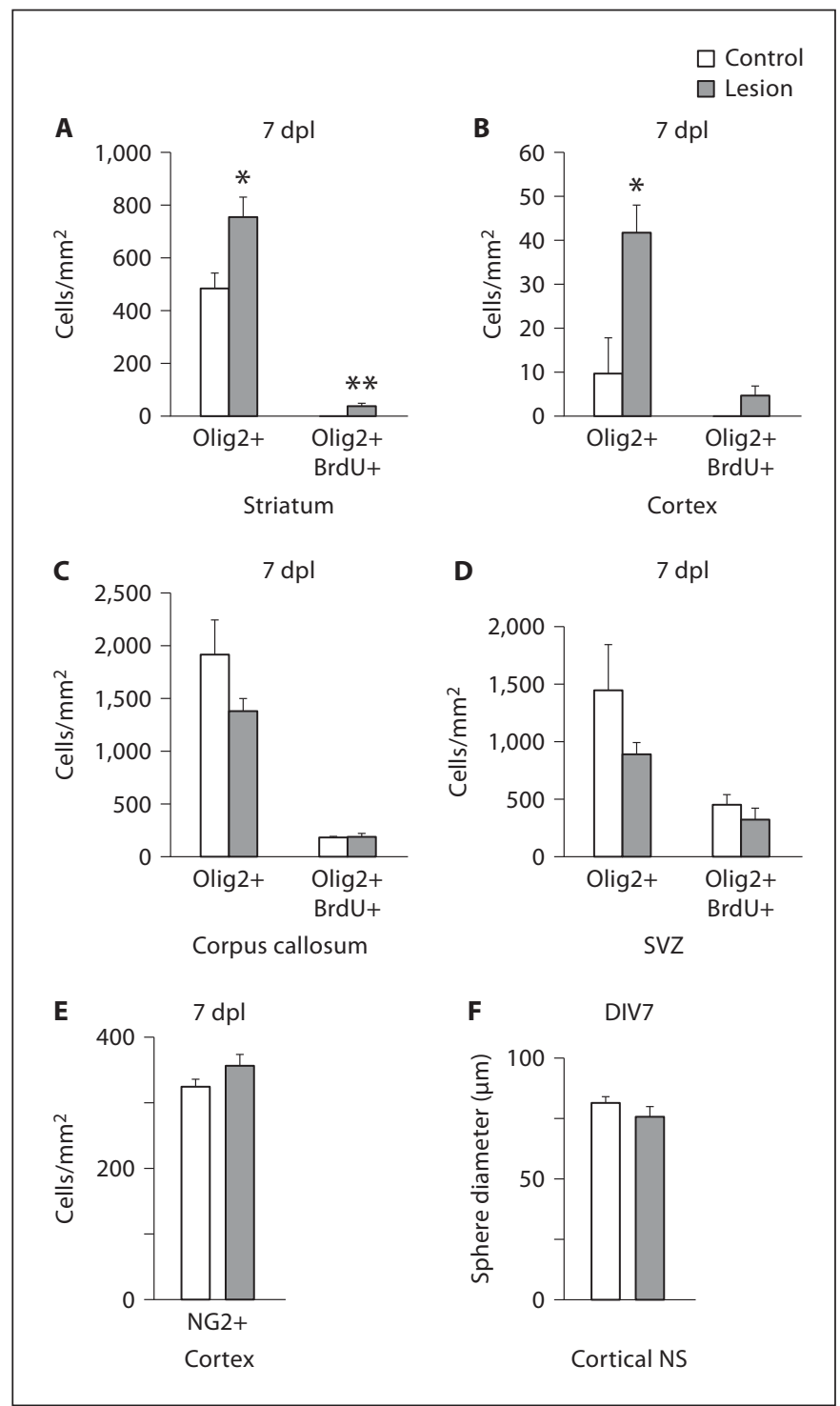

Fig. 6. Proliferation contributes to HI-induced increases in striatal Olig2+ cells. Immunofluorescence for Olig2 showed significant increases in Olig2+ cells $7 \mathrm{dpl}$ within the striatum (control, error bars represent SEM, $\mathrm{n}=3$ controls and 3 lesions, ${ }^{*} \mathrm{p}=0.044$ ) (A), and within the cortex $\left({ }^{*} \mathrm{p}=0.037\right)(\mathbf{B})$, but no change in Olig2+ cells within the corpus callosum (C), and particularly not within the SVZ (D). Double immunohistochemistry after BrdU administration at 5,6 and $7 \mathrm{dpl}$ showed a significant increase in newly born Olig2+/BrdU+ cells $7 \mathrm{dpl}$ in the striatum ( $\mathrm{n}=3$ controls and 3 lesions, $\left.{ }^{* *} \mathrm{p}=0.031\right)(\mathbf{A})$. No increase in newly born Olig2+/BrdU+ cells was seen in the cortex (B), although the overall number of BrdU+ cells (presumably macrophages) was increased (data not shown), nor in the corpus callosum (C), or in the SVZ (D). E Immunofluorescence for NG2 showed no significant increase in NG2+ cells in the cortex $7 \mathrm{dpl}$ (error bars represent SEM, $\mathrm{n}=3$ control and 3 lesioned animals). $\mathbf{F}$ Cortical NS did not differ in diameter whether derived from lesioned mice or nonlesioned controls (error bars represent SEM, $n=4$ separate experiments). 
The primacy of a local regenerative response to $\mathrm{HI}$ implicates NG2 cells as central players in this response. NG2 cells are the predominant neural progenitor cell found outside of the persistent germinal zones of the central nervous system. They are thought to be at least bipotential as the in vivo correlate of the oligodendrocyte-type 2 astrocyte progenitor cell or the glial-restricted progenitor cell. Through in vivo fate mapping studies using the NG2-Cre mice, NG2 cells have been shown either to give rise to oligodendrocytes or remain as NG2+ cells in white matter, whereas in gray matter they differentiate into oligodendrocytes or astrocytes. Within demyelinated lesions, NG2 cells proliferate and give rise to myelinating oligodendrocytes. Whether NG2 cells are tripotential, as some evidence indicates, is at present controversial [Zhu et al., 2008]. But whether truly bipotential or tripotential, NG2 cells remain the most likely source of new OPCs in addition to cycling extant OPCs. Whether HI might induce NG2 cells to differentiate into committed OPCs is a tractable hypothesis that has not been fully tested.

Despite the pervasive hope that NSPCs residing in postembryonic human brain germinal zones might be manipulated for use in cell replacement therapies, our findings suggest that future regenerative therapies may have better success if they target local progenitors that are capable of generating new OLs rather than SVZ cells that fail to migrate even after new OPCs are formed. Our work also demonstrates other specific obstacles to repair of white matter loss, including an insufficient mitotic response and impaired differentiation of OPCs. In turn, this suggests that therapeutic strategies must focus on (1) augmenting the mitotic rate of local and SVZ progenitors, (2) accelerating the maturation of NSPCs toward a migratory OPC phenotype, and/or (3) changing the extracellular matrix to one more hospitable for migration. We think that a particularly fruitful strategy will be to manipulate specific genetic pathways in order to enhance commitment of NSPCs towards an oligodendroglial fate, and we have begun to test whether this strategy can result in white matter regeneration following loss from HI.

\section{Acknowledgements}

This study was supported by grants NIH NINDS 5KO8 NS053529-05 (M.D.) and NIH NINDS RO1 20013 (J.A.K.).

\section{References}

Back SA, Han BH, Luo NL, Chricton CA, Xanthoudakis S, Tam J, Arvin KL, Holtzman DM (2002): Selective vulnerability of late oligodendrocyte progenitors to hypoxia-ischemia. J Neurosci 22:455-463.

- Brazel CY, Rosti RT 3rd, Boyce S, Rothstein RP, Levison SW (2004): Perinatal hypoxia/ischemia damages and depletes progenitors from the mouse subventricular zone. Dev Neurosci $26: 266-274$.

-Craig A, Ling Luo N, Beardsley DJ, WingatePearse N, Walker DW, Hohimer AR, Back SA (2003): Quantitative analysis of perinatal rodent oligodendrocyte lineage progression and its correlation with human. Exp Neurol 181:231-240.

-Dawson MR, Polito A, Levine JM, Reynolds R (2003): NG2-expressing glial progenitor cells: an abundant and widespread population of cycling cells in the adult rat CNS. Mol Cell Neurosci 24:476-488.

-Dizon ML, Shin L, Sundholm-Peters NL, Kang E, Szele FG (2006): Subventricular zone cells remain stable in vitro after brain injury. Neuroscience 142:717-725
Felling RJ, Snyder MJ, Romanko MJ, Rothstein RP, Ziegler AN, Yang Z, Givogri MI, Bongarzone ER, Levison SW (2006): Neural stem/ progenitor cells participate in the regenerative response to perinatal hypoxia/ischemia. J Neurosci 26:4359-4369.

Frost EE, Zhou Z, Krasnesky K, Armstrong RC (2009): Initiation of oligodendrocyte progenitor cell migration by a PDGF-A activated extracellular regulated kinase (ERK) signaling pathway. Neurochem Res 34:169-181.

Johnston MV, Hoon AH Jr (2006): Cerebral palsy. Neuromolecular Med 8:435-450.

Levison SW, Goldman JE (1997): Multipotential and lineage restricted precursors coexist in the mammalian perinatal subventricular zone. J Neurosci Res 48:83-94.

Ligon KL, Fancy SP, Franklin RJ, Rowitch DH (2006): Olig gene function in CNS development and disease. Glia 54:1-10.

- Lin TN, He YY, Wu G, Khan M, Hsu CY (1993): Effect of brain edema on infarct volume in a focal cerebral ischemia model in rats. Stroke 24:117-121.

- Liu Y, Silverstein FS, Skoff R, Barks JD (2002): Hypoxic-ischemic oligodendroglial injury in neonatal rat brain. Pediatr Res 51:25-33.
Menn B, Garcia-Verdugo JM, Yaschine C, Gonzalez-Perez O, Rowitch D, Alvarez-Buylla A (2006): Origin of oligodendrocytes in the subventricular zone of the adult brain. J Neurosci 26:7907-7918.

-Nam SC, Kim Y, Dryanovski D, Walker A, Goings G, Woolfrey K, Kang SS, Chu C, Chenn A, Erdelyi F, Szabo G, Hockberger P, Szele FG (2007): Dynamic features of postnatal subventricular zone cell motility: a two-photon time-lapse study. J Comp Neurol 505:190208.

Nishiyama A, Komitova M, Suzuki R, Zhu X (2009): Polydendrocytes (NG2 cells): multifunctional cells with lineage plasticity. Nat Rev Neurosci 10:9-22.

- Ong J, Plane JM, Parent JM, Silverstein FS (2005): Hypoxic-ischemic injury stimulates subventricular zone proliferation and neurogenesis in the neonatal rat. Pediatr Res 58:600-606.

- Plane JM, Liu R, Wang TW, Silverstein FS, Parent JM (2004): Neonatal hypoxic-ischemic injury increases forebrain subventricular zone neurogenesis in the mouse. Neurobiol Dis 16:585-595. 
- Rivers LE, Young KM, Rizzi M, Jamen F, Psachoulia K, Wade A, Kessaris N, Richardson WD (2008): PDGFRA/NG2 glia generate myelinating oligodendrocytes and piriform projection neurons in adult mice. Nat Neurosci 11:1392-1401.

-Samanta J, Burke GM, McGuire T, Pisarek AJ, Mukhopadhyay A, Mishina Y, Kessler JA (2007): BMPR1A signaling determines numbers of oligodendrocytes and calbindin-expressing interneurons in the cortex. J Neurosci 27:7397-7407.

-Segovia KN, McClure M, Moravec M, Luo NL, Wan Y, Gong X, Riddle A, Craig A, Struve J, Sherman LS, Back SA (2008): Arrested oligodendrocyte lineage maturation in chronic perinatal white matter injury. Ann Neurol 63:520-530.
-Sola A, Rogido M, Lee BH, Genetta T, Wen TC (2005): Erythropoietin after focal cerebral ischemia activates the Janus kinase-signal transducer and activator of transcription signaling pathway and improves brain injury in postnatal day 7 rats. Pediatr Res 57:481487.

Suzuki SO, Goldman JE (2003): Multiple cell populations in the early postnatal subventricular zone take distinct migratory pathways: a dynamic study of glial and neuronal progenitor migration. J Neurosci 23:42404250 .
Volpe JJ (2001): Neurobiology of periventricular leukomalacia in the premature infant. Pediatr Res 50:553-562.

Winter S, Autry A, Boyle C, Yeargin-Allsopp M (2002): Trends in the prevalence of cerebral palsy in a population-based study. Pediatrics 110:1220-1225.

Zaidi AU, Bessert DA, Ong JE, Xu H, Barks JD, Silverstein FS, Skoff RP (2004): New oligodendrocytes are generated after neonatal hypoxic-ischemic brain injury in rodents. Glia 46:380-390.

ZZu X, Bergles DE, Nishiyama A (2008): NG2 cells generate both oligodendrocytes and gray matter astrocytes. Development 135: 145-157. 